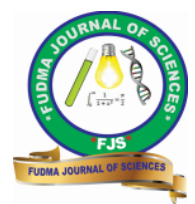

FUDMA Journal of Sciences (FJS)

ISSN online: $2616-1370$

ISSN print: 2645 - 2944

Vol. 4 No. 3, September, 2020, pp $416-425$

DOI: https://doi.org/10.33003/fjs-2020-0403-402

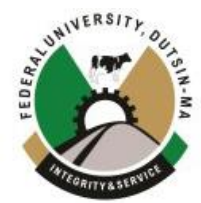

\title{
COMPOSITION AND DIVERSITY OF NON-TIMBER FOREST PRODUCTS (NTFPs) IN BATURIYA WETLAND GAME RESERVE, JIGAWA STATE, NIGERIA
}

\author{
${ }^{* 1}$ Saka, M. G., ${ }^{2}$ Aujara, Y. I., ${ }^{3}$ Ilu K. J., ${ }^{3}$ Salami , K. D. and ${ }^{4}$ Yakubu Mustapha \\ ${ }^{1}$ Department of Forestry and Wildlife, Modibbo Adama University of Technology Yola, Adamawa State, Nigeria \\ ${ }^{2}$ Department of Forestry Technology Binyaminu Usman Polytechnic Hadejia, Jigawa State, Nigeria \\ ${ }^{3}$ Department of Forestry and Wildlife Management, Federal University Dutse, Jigawa State, Nigeria \\ ${ }^{4}$ Department of Forestry Technology Hussani Adamu Federal Polytechnic Kazaure, Jigawa State, Nigeria
}

Corresponding Author's email: foristsalam@yahoo.com; yauidrisaujara@gmail.com

\begin{abstract}
Inadequate documentation and information of Non-Timber Forest Products (NTFPs) in the study sites call for the assessment of composition and diversity of the concern products. Therefore, the aim of the study is to assess the Composition and Diversity of Non- Timber Forest Products (NTFPs) in Baturiya Wetland Game Reserve, Jigawa State, Nigeria. A four (4) transects of $1 \mathrm{~km}$ length was laid at an interval of $400 \mathrm{~m}$. Likewise, in each transect, 4 plots of $100 \times 100 \mathrm{~m}$ was laid alternately along each transect at $200 \mathrm{~m}$ interval. Also four (4) quadrants of $1 \mathrm{~m} \times 1 \mathrm{~m}$ in size for small non-timber forest products was randomly laid in each $100 \times 100 \mathrm{~m}$ plot for each of the habitats in each plot, plant stocks identified were recorded. Data collected were analysed using Simpson index, Sorenson index and descriptive statistic. Results showed that Upland area had the highest species, number of individual and diversity of Non-Timber Forest Product followed by Swampy area and Fadama area with the values of $(94,1464, \mathrm{D}-0.981),(63,842, \mathrm{D}-0.970)$ and $(60,805, \mathrm{D}-0.969)$ respectively. Upland area and Swampy area had the highest similarity index of $78.5 \%$. The results suggest that the documentation, inventory and management of NTFPs should be addressed in operational plan to enhance its diversity.
\end{abstract}

Keywords: Diversity, floristic composition, Non-timber forest products, Baturiya Game reserve.

\section{INTRODUCTION}

Non-Timber Forest Products are useful substances, materials or commodity obtained from forest that do not required the harvesting of trees (FAO, 2018). The term Non- Timber Forest Products (NTFPs) emerged as an umbrella to recognize the products derived from various forest resources as a group. Non-timber forest products are plants and /or forest products that are valued for other purposes beside timber. They have been described as all biological materials of plant and animal origin other than wood that are extracted from the forest for human use and are mainly technological processing (Ibrahim et al., 2016)

Ramsar, (1994) defined wetlands as areas of marsh, fen, peat land or water, whether natural or artificial, permanent or temporary with water that is static or flowing, fresh, brackish or salt, including areas of marine water, the depth of which at low tide does not exceed six meters Ecological values of wetlands to humans consists of flood control, nutrient absorption and cycling which improve water quality, as well as protection of coastal communities from erosion and wave energy (Barbier et al., 1997). Economics values of wetlands include agriculture, provision of timber, fuel wood, and non-timber products such as cotton, silk and potash (Barbier et al., 19997). Non-Timber Forest Products (NTFP) are being increasingly recognized for their crucial roles in rural livelihoods, biodiversity conservation and export earnings. Wetland resources are used for many purposes and benefits which include soils for agriculture purpose, fishing for food and economy, trees for various purposes and reeds to shelter materials (Kar, 2013). Wetlands also refer to areas with water level very close to soil surface and possess water, plants, and soils. Wetlands have general functions and values which significantly recognizes the uniqueness of the environment (Nwankwoala, 2012). The importance of wetlands to life is enormous; it is used for recreational activities such as bird watching, sailing, research activities, nutrient decomposition and recycling. Globally, more than two billion people are dwelling in forests, depending on forest resources for subsistence, income and livelihood security (Ahenkan and Boon, 2011). Non timber forest products are considered to be vital for sustaining rural livelihoods, reducing rural poverty, biodiversity conservation and facilitating rural economic growth (Maske et al., 2011). World Health Organization estimated that about $80 \%$ of the population of the developing countries uses non-timber forest products to meet their health and nutritional needs (Olaniyi et al., 2013). The study of nontimber forest products has been dealt with by people from varied fields of study such as forestry, ethno-biology, economic botany, social development, natural resource economics, conservation biology, protected area management, agro-forestry, marketing, commercial development, ecological anthropology, cultural geography and human ecology. Therefore, objective of this study is to assess Diversity of Non-Timber Forest Products (NTFP's) in Baturiya Hadejia Wetland Game Reserve, Jigawa State, Nigeria, with a view to ensuring its sustainable management.

\section{MATERIALS AND METHODS \\ Study area}

Baturiya Hadejia- Wetlands is a wide expanse of flood plain wetlands situated in the Northeast Nigeria, the location lies in the sudano-sahelian zone, which is the zone between the SudanoSavanna in the south and the Sahel in the North. The wetland is found in Yobe state, located in the Northern part of Nigeria, which 
include the Nguru Lake (Eaton and Sarch, 1997). According to Wetlands, is located on the Latitude $12^{\circ} 20^{\prime} 0^{\prime \prime} \mathrm{N}$ to $12^{\circ} 40^{\prime} 0^{\prime \prime} \mathrm{N}$ and Ramsar, (1994), Baturiya which is a section of the Hadejia Nguru Longitude $10^{\circ} 10^{\prime} 0^{\prime \prime} \mathrm{E}$ to $10^{\circ} 30^{\prime} 0{ }^{\prime \prime E}$

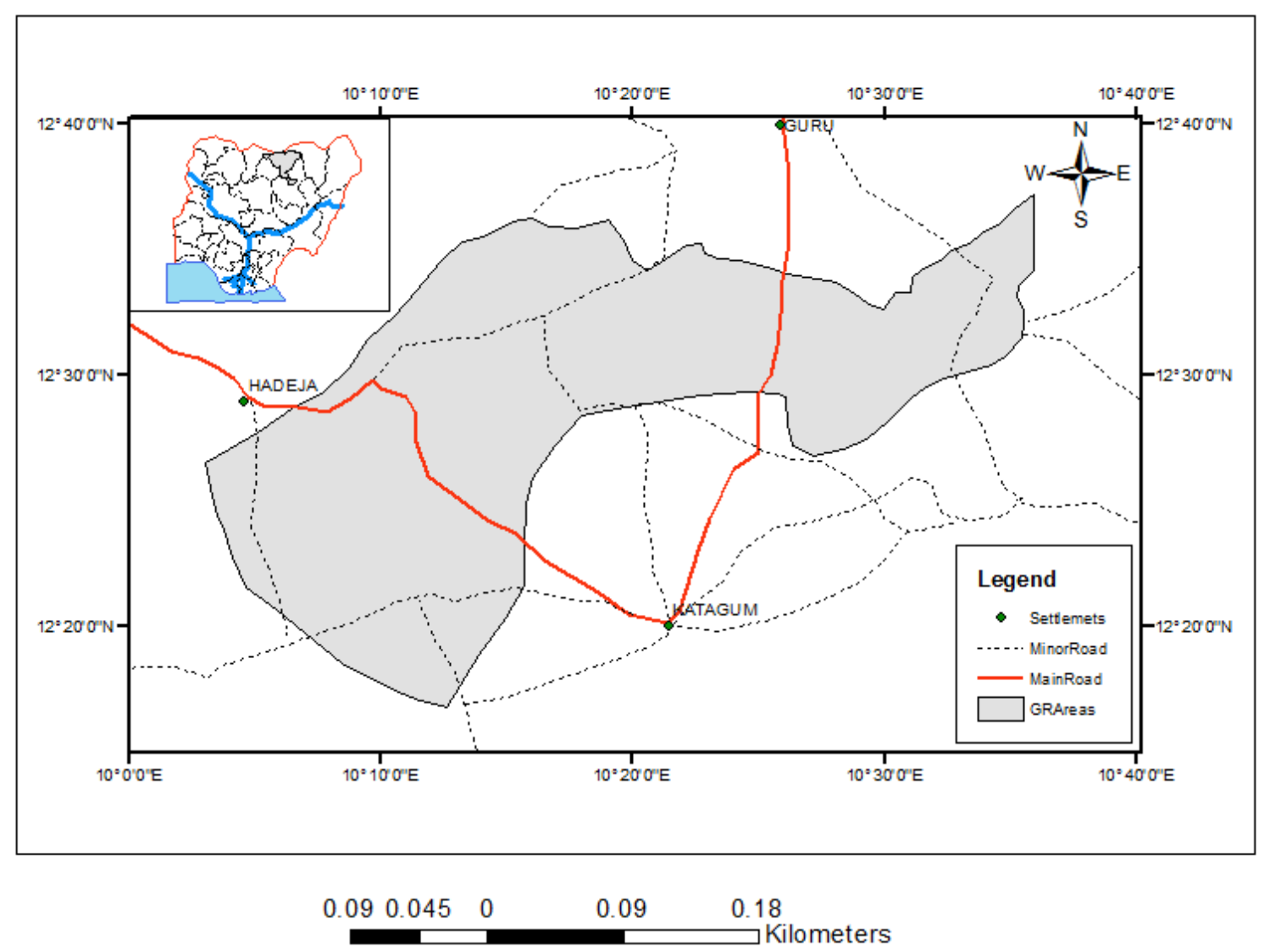

Figure 1: Map of Baturiya Wetland Game Reserve

\section{Sourc: GIS Laboratory, Geography Department MAUTECH Yola 2017}

\section{Sampling technique}

Systematic sampling method was adopted for this study, in which the study area was stratified according to existing habitats (Uplands, Fadama and Swamp) in the game reserve. In each habitat, 4 transect of $1 \mathrm{~km}$ length was laid at an interval of $400 \mathrm{~m}$. Likewise, in each transect, four (4) plots of $100 \times 100 \mathrm{~m}$ was laid alternately along each transect at $200 \mathrm{~m}$ interval. Also five (5) quadrants of $1 \mathrm{~m} \mathrm{x} 1 \mathrm{~m}$ in size was randomly laid in each $100 \times 100 \mathrm{~m}$ plot for each of the habitats

\section{Data collection}

In each plot, non-timber forest products identified were recorded, while voucher specimen was used for collection of species that could not be identified in the field, and later were taken to the herbarium of Department of Forestry Federal University Dutse (FUD) for identification

\section{Data analysis}

(a) Descriptive Statistics was used in presenting the checklist of the non-timber forest products of the study area.

(b) Simpson diversity index was employed in assessing the diversity of Non-Timber Forest Products and is of the form 
Simpson index $\quad D=1-\left(\frac{\sum n(n-1)}{N(N-1)}\right)$

Where $\mathrm{n}=$ total number of organism of a particular species,

$\mathrm{N}=$ the total number of organisms of all species

(c) Sorensen's species similarity index between two sites was calculated using equation

$S I=\left(\frac{2 C}{a+b}\right) X 100 . \%$

Where:

$\mathrm{C}=$ number of species at sites $\mathrm{a}, \mathrm{b}$

$a, b=$ number of species at sites $a, b$

\section{RESULTS AND DISCUSSIONS}

\section{Floristic composition}

A total one hundred and forty (140) species of Non-Timber Forest Products were identified in 101 genera and 46 families in the game reserve. Fadama area is more peculiar with Acanthaceae, Combretaceae, Balantacaea, Cesalpinineae and Ranidae. Mimosaceae had the highest number of individual and plant species in the study area: Acacia hockii, Acacia polyacantha, Acacia atathecantha, Acacia campyiacantha, Acacia erioloba, Acacia karro, Acacia macrostachya, Acacia oerfota, Acacia Senegal, Albizia chevalieri, Parkia biglobosa, Ziziphus abyssinica, Ziziphus mauritiana, Ziziphus microphylla, Ziziphus mucronata and Zizyphus spina. Families like Apiaceae (Centella astiatica), Olacaceae (Ximenia Americana), Tamaraceae (Tamarindus indica), Lamiaceae (Sienna obtusifolia), Polygalceae (Securideae longependilata) and Aracaceae (Pistia stratiotes) had the least number of species.

Table 1: Floristic distribution of Non Timber Forest Products and Diversity index

\begin{tabular}{ccccc}
\hline S/N & Habitat & $\begin{array}{l}\text { Number of } \\
\text { plant }\end{array}$ & n (n-1) & $\begin{array}{c}\text { Simpson } \\
\text { index }\end{array}$ \\
\hline 1 & Upland area & 1464 & 40316 & 0.981 \\
2 & Fadama area & 842 & 21628 & 0.969 \\
3 & $\begin{array}{c}\text { Swampy } \\
\text { area }\end{array}$ & 805 & 19360 & 0.970 \\
\hline
\end{tabular}

Source: Field survey, (2019)

Diversity of Non-Timber Forest Product in Baturiya Game Reserve

Non-timber forest Products species diversity in habitat I (upland), the result indicated that upland habitat comprises of ninety-four (94) species in twenty-six (26) family and sixty-five (65) genera with diversity index of D- 0.981. Non-Timber Forest Products Species Diversity in habitat II (Fadama). Results of non-timber forest products species diversity shows that fadama habitat comprise of sixty (60) species in twenty-five (21) family and forty-three (43) genera with diversity index of D- 0.969. Non-Timber Forest Products Species Diversity in habitat III (swamp). Results of nontimber forest products species diversity shows that swamp habitat comprise of sixty (63) species in twenty-two (23) family and forty four (44) genera with diversity index of D- 0.970 . The similarity index between the Upland area and Swampy area sites is $78.5 \%$ was proved to be the best.

Findings on NTFPs diversity indicated that Baturiya Game Reserve contained the greatest diversity in terms of non-timber forest products species diversity. The diversity of non-timber forest products was high across the three major habitats namely upland, fadama and swamp, there were disproportionately distributed among non-timber forest products diversity across the habitats thus upland has the highest Simpson diversity index of D- 0.981 followed by swamp with non-timber forest products with Simpson diversity index of D- 0.970 and fadama with least diversity index of D- 0.969 . According to Aramd et al. (2016), the value of D ranges from 0 to 1 with this index, 0 represent high diversity and 1 , no diversity thus lowers the value of $\mathrm{D}$, the greater is the species diversity. Finding reveals that the game reserve is diverse in term of NTFPs because the diversity of all the habitats ranges from $0.69-0.981$. Probably the even distribution of non-timber forest products may have given rise to a uniform habitats structure in the reserve. This is in line with Suraj and Narayan, (2016) who reported that Simpson of diversity index among the three different sites, were 0.988 (Control site 3), 0.328 (Site 1), and 0.213 (Site 2), indicating that (Site 3) has higher diversity values in comparison to the Site1 and 2. The results of plant species similarity index $(71.0 \%, 78.5 \%, 61.5 \%$ between Upland area and Fadama area, Upland area and Swampy area, Swampy area and Fadama area respectively) revealed that tree species in Upland area and Swampy area are more similar than any other site combinations (Table 2). This implies that there is higher number of common tree species in the study sites. However, Onyekwelu et al. (2008), reported moderate similarity index between Queen's and Elephant forest, Queen's and Oluwa forest, Oluwa and Elephant forest with value of $63.4 \%, 58.3 \%$ and $47.4 \%$ respectively. Salami (2017), also observed moderate similarity index between Omo Biosphere Reserve and Gambari Forest Reserve with value of $58.33 \%$. 
Table 2: Site characteristics and similarity index

\begin{tabular}{|c|c|c|c|c|}
\hline Habitat Combination & Similarity index & No of family & No of species & No of genus \\
\hline Upland area x Fadama area & 71.0 & - & - & - \\
\hline Upland area $\mathrm{x}$ Swampy area & 78.5 & - & - & - \\
\hline Swampy area $\mathrm{x}$ Fadama area & 61.5 & - & - & - \\
\hline \multicolumn{5}{|l|}{ Habitat } \\
\hline Upland area & - & 94 & 26 & 65 \\
\hline Fadama area & - & 60 & 21 & 43 \\
\hline Swampy area & - & 63 & 23 & 44 \\
\hline
\end{tabular}

Source: Field survey, (2019)

\section{CONCLUSION}

Baturiya Game Reserve comprises of diverse and abundance plant species especially in the Upland area and Fadama areas which is worth of conserving for ecology, economy and biodiversity values. Still, the study area is under high pressure of unsustainable harvests, intensification of agriculture and sporadic debarking by traditional medical practitioners which may results to the depletion of non timber forest products in the study area. Therefore, there is need for proper inventory, documentation and management of NTFPs in the game reserve planning to enhance its genetic composition and diversity.

\section{CONFLICT OF INTRESTS}

The authors have not declared any conflict of interest.

\section{ACKNOWLEDMENT}

We thank the entire staff of Baturiya Game Reserve Ministry of Environment Jigawa State, Nigeria for their cooperation rendered during the study, and the field guides for their assistance.

\section{REFERENCES}

Ahenkan, A. and Boon, E. (2011). Non-timber forest products (NTFPs): Clearing the confusion in semantics. Journal of Human Ecology, 33(1): 1-9.

Aramde Fetene, Tsegaye Bekele and Mulugeta Lemenih, (2017) Diversity of non-timber forest products (ntfps) and their source species in Menageshasuba forest Ethiopia. Journal. Biological Science., 9(1):11-34, 2010.

Barbier, E., Acreman, M. and Knowler, D. (1997). Economic Valuation of Wetlands: A Guide for Policy Makers and Planners, Ramsar Convention Bureau. Gland, Switzerland.

Eaton, D. and Sarch M. T (1997). The economic importance of wild resources in the Hadejia-Nguru Wetlands, Nigeria.

Food and Agricultural Organisation (FAO)., (2018). Non-Timber Forest Products from Restoration to Income Generation, Forestry Paper no 112 Rome Italy

Ibrahim. A.O.1, Ampitan.T.A.1, Adeniji.O.A.1, Olayinka, A.P.1,
Babatunde, K.O.1 (2016) utilization of Non-Timber Forest Products (NTFPs) in New Bussa, Nigeria. International Journal of Research in Agriculture and Forestry 3(10):1-7 Kar D (2013). Wetlands and Lakes of the World, New Delhi: Springer, India.

Maske, M., Mungole, A., Kamble, R., Chaturvedi, A. and Chaturvedi, A. (2011). Impact of non-timber forest produces (NTFPs) on rural tribes' economy in Gondia district of Maharashtra, India. Achieves of Applied Science Research, 3(30): 109-114.

Maske, M., Mungole, A., Kamble, R., Chaturvedi, A. and Chaturvedi, A. (2011).Impact of non-timber forest produces (NTFPs) on rural tribes' economy in Gondia district of Maharashtra, India. Achieves of Applied Science Research, 3(30):109-114.

Olaniyi, O.A., Akintonde, J.O. and Adetumbi, S.I. (2013). Contribution of non-timber forest products to household food security among rural women in Iseyin local government area of Oyo state, Nigeria. Research on Humanities and Social Sciences, 3(7): 41-50.

Onyekwelu, J.C., Mosandi, R. and Stimm, B. (2008). Tree species diversity and soil status of primary and degraded tropical rainforest ecosystems in South Western Nigeria. Journal of Tropical of Forest Science, 20(3):198-204pp

Ramsar, C. (1994). Convention on Wetlands of International Importance Especially as Waterfowl Habitat, United Nations Educational, Scientific and Cultural Organization (UNESCO): Paris, France.

Salami, K. D. (2017). Tree species Diversity and Soil status of Omo Biosphere and Gambari Forest reserves in Southwestern Nigeria. Ph.D Thesis, Department of Forest Resources Management, University of Ibadan, Nigeria.

Suraj Sharma1; Parthankar Choudhury and Narayan Chetry (2016): Diversity of Non-Timber The Economist (2000). Poverty and property rights. 358 (8215): 19-22The effect of wealth and markets on the economic behaviour of Tawahka Amerindians in Honduras. 
( $\mathrm{PhD}$ Thesis University of Amsterdam). Tropenbos Series 19. Wageningen: Tropenbos International

\section{APPENDIXES}

Table 2: Non-timber forest products Species diversity in the upland habitat in Baturiya Wetland.

\begin{tabular}{|c|c|c|c|c|}
\hline $\mathrm{S} / \mathrm{N}$ & Scientific Name & Family & No. of plants & $\mathrm{n}(\mathrm{n}-1)$ \\
\hline 1 & Acacia hockii & Mimosaceae & 10 & 90 \\
\hline 2 & Acacia polyacantha & Mimosaceae & 23 & 506 \\
\hline 3 & Acacia atathecantha & Mimosaceae & 40 & 1560 \\
\hline 4 & Acacia campyiacantha & Mimosaceae & 20 & 380 \\
\hline 5 & Acacia erioloba & Mimosaceae & 21 & 420 \\
\hline 6 & Acacia karro & Mimosaceae & 16 & 240 \\
\hline 7 & Acacia macrostachya & Mimosaceae & 50 & 2450 \\
\hline 8 & Acacia oerfota & Mimosaceae & 13 & 156 \\
\hline 9 & Acacia Senegal & Mimosaceae & 40 & 1560 \\
\hline 10 & Acantho hispidum & Acanthacea & 20 & 380 \\
\hline 11 & Adansonia digitate & Bombacaceae & 8 & 56 \\
\hline 12 & Ageratum coyzoides & Compositae & 16 & 240 \\
\hline 13 & Albizia chevalieri & Mimosaceae & 16 & 240 \\
\hline 14 & Alysicarpus vaginalis & Grammenia & 20 & 380 \\
\hline 15 & Androphogan gayanus & Grammenia & 40 & 1560 \\
\hline 16 & Anogeissas leicarpus & Combretaceae & 15 & 210 \\
\hline 17 & Anona senegalensis & Annonaceae & 30 & 870 \\
\hline 18 & Balanites egyptiaca & Balanitaceae & 14 & 182 \\
\hline 19 & Bombax costatum & Bombacaceae & 12 & 132 \\
\hline 20 & Borassus aegytinca & Palmea & 3 & 6 \\
\hline 21 & Borassus aethiopum & Palmea & 5 & 20 \\
\hline 22 & Carissa edulis & Apocynaceae & 3 & 6 \\
\hline 23 & Cassia italic & Calsalpiniceae & 3 & 6 \\
\hline 24 & Cassia singuena & Calsalpiniceae & 2 & 2 \\
\hline 25 & Cassia arereh & Calsalpiniceae & 7 & 42 \\
\hline 26 & Cassia tora & Calsalpiniceae & 60 & 3540 \\
\hline 27 & Celtis infergriflora & Combretaceae & 19 & 342 \\
\hline 28 & Centella astiatica & Apiaceae & 2 & 2 \\
\hline 29 & Combretum lamprocarpum & Combretaceae & 25 & 600 \\
\hline 30 & Combretum micranthum & Combretaceae & 2 & 2 \\
\hline 31 & Daniellia oliveri & Calsalpiniceae & 7 & 42 \\
\hline 32 & Detaruim macrocarpum & Calsalpiniceae & 2 & 2 \\
\hline 33 & Dichrosachys glomerata & Fabaceae & 4 & 12 \\
\hline 34 & Dichrosachys tcinerea & Fabaceae & 6 & 30 \\
\hline 35 & Digitaria debilis & Grammenia & 30 & 870 \\
\hline 36 & Diospyros mespiliformis & Ebenaceae & 42 & 1722 \\
\hline 37 & Entandra africana & Ebenaceae & 16 & 240 \\
\hline 38 & Erthrina senegalensis & Fabaceae & 9 & 72 \\
\hline
\end{tabular}




\begin{tabular}{|c|c|c|c|c|}
\hline 39 & Erthropleum suaveolens & Fabaceae & 18 & 306 \\
\hline 40 & Euphorbia basalefera & Euphorbiacea & 9 & 72 \\
\hline 41 & Euphorbia lateriflora & Euphorbiacea & 2 & 2 \\
\hline 42 & Euphorbia poisson & Euphorbiacea & 6 & 30 \\
\hline 43 & Ficus polita & Moraceae & 7 & 42 \\
\hline 44 & Ficus sycomorus & Moraceae & 18 & 306 \\
\hline 45 & Fiscus thonningi & Moraceae & 9 & 72 \\
\hline 46 & Fiscus iteopyla & Moraceae & 10 & 90 \\
\hline 47 & Fiscus platyphylla & Moraceae & 12 & 132 \\
\hline 48 & Gardenia aqualla & Fabaceae & 20 & 380 \\
\hline 49 & Guiera senegalensis & Combretaceae & 18 & 306 \\
\hline 50 & Guinea grass & Grammenia & 30 & 870 \\
\hline 51 & Hymenocardia acida & Euphorbiacea & 17 & 272 \\
\hline 52 & Hyphaene thebaica & Palmea & 90 & 8010 \\
\hline 53 & Imperata cylindrical & Grammenia & 40 & 1560 \\
\hline 54 & Indigofera arrtecta & Fabaceae & 10 & 90 \\
\hline 55 & Ipomoea muricata & Grammenia & 15 & 210 \\
\hline 56 & Jatropha chevalieri & Euphorbiacea & 9 & 72 \\
\hline 57 & Jatropha curcas & Euphorbiacea & 29 & 812 \\
\hline 58 & Lannea acida & Anacardiaceae & 10 & 90 \\
\hline 59 & Lantana camara roxb & Verbanaceae & 4 & 12 \\
\hline 60 & Leptademia hastate & Asclepidaceae & 6 & 30 \\
\hline 61 & Mangifera indica & Anacardiaceae & 24 & 552 \\
\hline 62 & Mimosa pigra & Fabaceae & 3 & 6 \\
\hline 63 & Paninari macropylla & Steculiaceae & 17 & 272 \\
\hline 64 & Parkia biglobosa & Mimosaceae & 30 & 870 \\
\hline 65 & Phoenix dactylifera & Palmea & 18 & 306 \\
\hline 66 & Phoenix llernianus & Palmea & 2 & 2 \\
\hline 67 & Phoenix mullerrianus & Palmea & 10 & 90 \\
\hline 68 & Phoenix reclinata & Palmea & 3 & 6 \\
\hline 69 & Physalis divericata & Solanaceae & 25 & 600 \\
\hline 70 & Pistia stratiotes & Araceae & 13 & 156 \\
\hline 71 & Prosopis africana & Mimosaceae & 2 & 2 \\
\hline 72 & Rauvolfia caffra & Apocynaceae & 9 & 72 \\
\hline 73 & Saba florida & Apocynaceae & 2 & 2 \\
\hline 74 & Sclerocarya birrea & Anacardiaceae & 2 & 2 \\
\hline 75 & Securideae longependilata & Polygalceae & 2 & 2 \\
\hline 76 & Sienna obtusifolia & Lamiaceae & 6 & 30 \\
\hline 77 & Solanum nigrum & Steculiaceae & 2 & 2 \\
\hline 78 & Sphaeranthus angustifolius & Grammenia & 10 & 90 \\
\hline 79 & Spondia nombin & Steculiaceae & 21 & 420 \\
\hline 80 & Steculia settigera & Steculiaceae & 19 & 342 \\
\hline 81 & Steculia tregecantha & Steculiaceae & 6 & 30 \\
\hline
\end{tabular}




\begin{tabular}{llllc}
\hline 82 & Steculia virosa & Euphorbiacea & 2 & 2 \\
83 & Sterculia setigera & Steculiaceae & 6 & 30 \\
84 & Strophanthus gratus & Apocynaceae & 4 & 12 \\
85 & Tamarindus indica & Tamaraceae & 30 & 870 \\
86 & Tridax procumbens & Grammenia & 10 & 90 \\
87 & Vitellaria paradoxa & Mimosaceae & 29 & 812 \\
88 & Vitex doniana & Verbanaceae & 18 & 306 \\
89 & Ximenia americana & Olaceae & 20 & 380 \\
90 & Ziziphus abyssinica & Mimosaceae & 10 & 90 \\
91 & Ziziphus mauritiana & Mimosaceae & 29 & 812 \\
92 & Ziziphus microphylla & Mimosaceae & 6 & 30 \\
93 & Ziziphus mucronata & Mimosaceae & 9 & 72 \\
94 & Zizyphus spina & Mimosaceae & 5 & 20 \\
Total & & & 1464 & 40316 \\
\hline
\end{tabular}

Source: Field survey, 2019

Table 3: Non-timber forest products species diversity of sampled fadama habitat in Baturiya game reserve

\begin{tabular}{|c|c|c|c|c|}
\hline $\mathbf{S} / \mathbf{N}$ & Scientific Name & Family Name & No. plants & $\mathbf{n}(\mathbf{n}-1)$ \\
\hline 1 & Acacia polyacantha & Mimosaceae & 10 & 90 \\
\hline 2 & Acacia macrostachya & Mimosaceae & 19 & 342 \\
\hline 3 & Acacia nilotica & Mimosaceae & 60 & 3540 \\
\hline 4 & Acacia Senegal & Mimosaceae & 36 & 1260 \\
\hline 5 & Acantho hispidum & Acanthacea & 6 & 30 \\
\hline 6 & Adansonia digitate & Bombacaceae & 23 & 506 \\
\hline 7 & Anogeissus leicarpus & Combretaceae & 30 & 870 \\
\hline 8 & Anona senegalensis & Annonaceae & 10 & 90 \\
\hline 9 & Balanites egyptiaca & Balanitaceae & 14 & 182 \\
\hline 10 & Boehavia diffusa & Nyitaginaceae & 7 & 42 \\
\hline 11 & Bombax costatum & Bombacaceae & 18 & 306 \\
\hline 12 & Borreria stachydea & Rubiaceae & 6 & 30 \\
\hline 13 & Borreria verticellata & Rubiaceae & 2 & 2 \\
\hline 14 & Cassia italic & Calsalpiniceae & 10 & 90 \\
\hline 15 & Cassia singuena & Calsalpiniceae & 9 & 72 \\
\hline 16 & Cassia arereh & Calsalpiniceae & 4 & 12 \\
\hline 17 & Celtis infergriflora & Combretaceae & 2 & 2 \\
\hline 18 & Centella astiatica & Apiaceae & 2 & 2 \\
\hline 19 & Combretum lamprocarpum & Combretaceae & 7 & 42 \\
\hline 20 & Combretum micranthum & Combretaceae & 6 & 30 \\
\hline 21 & Detaruim macrocarpum & Calsalpiniceae & 7 & 42 \\
\hline 22 & Dichrostachys cinema & Mimosaceae & 2 & 2 \\
\hline 23 & Diospyros mespiliformis & Ebenaceae & 46 & 2070 \\
\hline 24 & Entandra africana & Ebenaceae & 5 & 20 \\
\hline 25 & Euphorbia basalefera & Euphorbiacea & 2 & 2 \\
\hline 26 & Euphorbia lateriflora & Euphorbiacea & 6 & 30 \\
\hline
\end{tabular}




\begin{tabular}{|c|c|c|c|c|}
\hline 27 & Euphorbia poisson & Euphorbiacea & 3 & 6 \\
\hline 28 & Ficus polita & Moraceae & 6 & 30 \\
\hline 29 & Ficus sycomorus & Moraceae & 10 & 90 \\
\hline 30 & Fiscus thonningi & Moraceae & 18 & 306 \\
\hline 31 & Fiscus iteopyla & Moraceae & 2 & 2 \\
\hline 32 & Fiscus platyphylla & Moraceae & 2 & 2 \\
\hline 33 & Gardenia aqualla & Fabaceae & 14 & 182 \\
\hline 34 & Guiera senegalensis & Combretaceae & 22 & 462 \\
\hline 35 & Hyphaene thebaica & Palmea & 22 & 462 \\
\hline 36 & Indigofera arrtecta & Fabaceae & 9 & 72 \\
\hline 37 & Lannea acida & Anacardiaceae & 4 & 12 \\
\hline 38 & Lantana camara roxb & Verbenacea & 10 & 90 \\
\hline 39 & Lawsonia inermis & Lythraceae & 30 & 870 \\
\hline 40 & Mangifera indica & Anacardiaceae & 40 & 1560 \\
\hline 41 & Mimosa pigra & Fabaceae & 2 & 2 \\
\hline 42 & Mitrigynia inermis & Rubiaceae & 39 & 1482 \\
\hline 43 & Moringa oleafera & Moringaceae & 40 & 1560 \\
\hline 44 & Nymphaea lotus & Nymphaeceae & 50 & 2450 \\
\hline 45 & Paninari ployandra & Rosaceae & 2 & 2 \\
\hline 46 & Piliostigma reticulatum & Calsalpiniceae & 21 & 420 \\
\hline 47 & Pterocarpus erinaceus & Fabaceae & 6 & 30 \\
\hline 48 & Pterocarpus santalinoides & Fabaceae & 2 & 2 \\
\hline 49 & Rana clamiton & Ranidae & 9 & 72 \\
\hline 50 & Rana escukate & Ranidae & 18 & 306 \\
\hline 51 & Sclerocarya birrea & Anacardiaceae & 7 & 42 \\
\hline 52 & Senna occidentalis & Fabaceae & 12 & 132 \\
\hline 53 & Senna singuena & Fabaceae & 9 & 72 \\
\hline 54 & Sienna obtusifolia & Lamiaceae & 5 & 20 \\
\hline 55 & Tamarindus indica & Tamaricaceae & 12 & 132 \\
\hline 56 & Vitex doniana & Verbenacea & 21 & 420 \\
\hline 57 & Ximenia americana & Olacaceae & 19 & 342 \\
\hline 58 & Xlopia parviflora & Fabaceae & 16 & 240 \\
\hline 59 & Ziziphus microphylla & Mimosaceae & 6 & 30 \\
\hline 60 & Zizyphus spina & Mimosaceae & 5 & 20 \\
\hline Total & & & 842 & 21628 \\
\hline
\end{tabular}

Source: Field survey, 2019

Table 4: Non-timber forest products diversity of sampled Swamp habitat in Baturiya wetland

\begin{tabular}{lllcc}
\hline S/N & Scientific Name & Family Name & No. of plants & n(n-1) \\
\hline 1 & Acacia hockii & Mimosaceae & 17 & 272 \\
2 & Acacia atathecantha & Mimosaceae & 10 & 90 \\
3 & Acacia erioloba & Mimosaceae & 15 & 210 \\
4 & Acacia karro & Mimosaceae & 8 & 56 \\
5 & Acacia macrostachya & Mimosaceae & 9 & 72
\end{tabular}




\begin{tabular}{|c|c|c|c|c|}
\hline 6 & Acacia nilotica & Mimosaceae & 30 & 870 \\
\hline 7 & Acacia Senegal & Mimosaceae & 27 & 702 \\
\hline 8 & Agaricus bispore & Ascomycetes & 50 & 2450 \\
\hline 9 & Agaricus bulbosa & Ascomycetes & 40 & 1560 \\
\hline 10 & Anogeissus leicarpus & Combretaceae & 22 & 462 \\
\hline 11 & Balanites egyptiaca & Balanitaceae & 16 & 240 \\
\hline 12 & Borassus aegytinca & Palmea & 8 & 56 \\
\hline 13 & Borassus aethiopum & Palmea & 4 & 12 \\
\hline 14 & Borreria stachydea & Rubiaceae & 6 & 30 \\
\hline 15 & Borreria verticellata & Rubiaceae & 2 & 2 \\
\hline 16 & Cassia tora & Calsalpiniceae & 2 & 2 \\
\hline 17 & Detarium macrocarpum & Fabaceae & 18 & 306 \\
\hline 18 & Detaruim macrocarpum & Calsalpiniceae & 10 & 90 \\
\hline 19 & Dichrostachys cinema & Mimosaceae & 4 & 12 \\
\hline 20 & Diospyros mespiliformis & Ebenaceae & 47 & 2162 \\
\hline 21 & Entandra Africana & Ebenaceae & 7 & 42 \\
\hline 22 & Entandra bilbosa & Mimosaceae & 9 & 72 \\
\hline 23 & Euphorbia basalefera & Euphorbiacea & 9 & 72 \\
\hline 24 & Euphorbia lateriflora & Euphorbiacea & 15 & 210 \\
\hline 25 & Euphorbia poisson & Euphorbiacea & 6 & 30 \\
\hline 26 & Ficus polita & Moraceae & 6 & 30 \\
\hline 27 & Ficus sycomorus & Moraceae & 8 & 56 \\
\hline 28 & Fiscus thonningi & Moraceae & 4 & 12 \\
\hline 29 & Fiscus iteopyla & Moraceae & 9 & 72 \\
\hline 30 & Fiscus platyphylla & Moraceae & 2 & 2 \\
\hline 31 & Guiera senegalensis & Combretaceae & 18 & 306 \\
\hline 32 & Hymenocardia acida & Euphorbiacea & 9 & 72 \\
\hline 33 & Hyphaene thebaica & Palmea & 11 & 110 \\
\hline 34 & Jatropha curcas & Euphorbiacea & 20 & 380 \\
\hline 35 & Lannea acida & Anacardiaceae & 6 & 30 \\
\hline 36 & Lawsonia inermis & Lythraceae & 8 & 56 \\
\hline 37 & Leptoptilos crumeniferus & Ciconiidae & 2 & 2 \\
\hline 38 & Mangifera indica & Anacardiaceae & 20 & 380 \\
\hline 39 & Mimosa pigra & Fabaceae & 2 & 2 \\
\hline 40 & Mitrigynia inermis & Rubiaceae & 55 & 2970 \\
\hline 41 & Moringa oleafera & Moringaceae & 6 & 30 \\
\hline 42 & Nymphaea lotus & Nymphaeceae & 48 & 2256 \\
\hline 43 & Paninari macropylla & Sterculiaceae & 6 & 30 \\
\hline 44 & Paninari ployandra & Rosaceae & 6 & 30 \\
\hline 45 & Parkia biglobosa & Mimosaceae & 4 & 12 \\
\hline 46 & Prosopis africana & Mimosaceae & 3 & 6 \\
\hline 47 & Pterocarpus erinaceus & Fabaceae & 21 & 420 \\
\hline 48 & Pterocarpus santalinoides & Fabaceae & 2 & 2 \\
\hline
\end{tabular}




$\begin{array}{lllcc}49 & \text { Rana clamiton } & \text { Ranidae } & 20 & 380 \\ 50 & \text { Rana escukate } & \text { Ranidae } & 31 & 930 \\ 51 & \text { Senna occidentalis } & \text { Fabaceae } & 9 & 72 \\ 52 & \text { Senna singuena } & \text { Fabaceae } & 6 & 30 \\ 53 & \text { Spondia nombin } & \text { Sterculiaceae } & 5 & 20 \\ 54 & \text { Stryculia virosa } & \text { Euphorbiacea } & 7 & 42 \\ 55 & \text { Tamarindus indica } & \text { Tamaricaceae } & 8 & 56 \\ 56 & \text { Vitellaria paradoxa } & \text { Mimosaceae } & 3 & 6 \\ 57 & \text { Vitex doniana } & \text { Verbenacea } & 4 & 12 \\ 58 & \text { Xerus ruticus } & \text { Scuiridae } & 2 & 2 \\ 59 & \text { Ximenia americana } & \text { Olacaceae } & 18 & 306 \\ 60 & \text { Xlopia parviflora } & \text { Fabaceae } & 6 & 30 \\ 61 & \text { Ziziphus abyssinica } & \text { Mimosaceae } & 6 & 30 \\ 62 & \text { Ziziphus microphylla } & \text { Mimosaceae } & 3 & 6 \\ 63 & \text { Zizyphus spina } & \text { Mimosaceae } & 10 & 90 \\ \text { Total } & & & \mathbf{8 0 5} & \mathbf{1 9 3 6 0}\end{array}$

Source: Field survey, 2019 